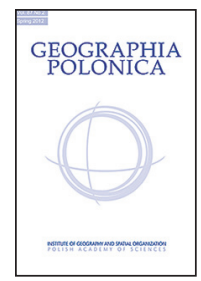

\title{
DAILY MOBILITY OF DISABLED PEOPLE FOR HEALTHCARE FACILITIES AND THEIR ACCESSIBILITY IN URBAN SPACE
}

\author{
Zbigniew Taylor ${ }^{1} \cdot$ Iwona Józefowicz ${ }^{2}$ \\ ${ }^{1}$ Institute of Geography and Spatial Organization \\ Polish Academy of Sciences \\ Twarda 51/55, 00-818 Warsaw: Poland \\ e-mail adress: z.taylor@twarda.pan.pl \\ ${ }^{2}$ Kazimierz Wielki University \\ Institute of Geography \\ Mińska 15, 85-428 Bydgoszcz: Poland \\ e-mail adress: jozefowicz.ukw@wp.pl
}

\begin{abstract}
This paper presents findings from an empirical study of diurnal trips made by disabled people to healthcare facilities distributed across urban space. The study was carried out in the city of Bydgoszcz, Poland, while the subsequent analysis is based on the authors' inventory of healthcare facilities and interviews. Data gathered from interviews with 450 disabled people plus 150 able-bodied members of the same households bring out great differences in daily mobility between the two social categories. The daily mobility of disabled people in relation to healthcare is much more tangible than that involving their non-disabled counterparts. Disabled people opt to commute further and for a longer time to the establishments providing comprehensive medical services of high quality, even if the architectural availability of some of these facilities is unsatisfactory. In contrast, their able-bodied counterparts mostly choose general practitioners situated near to their home areas, rather than travelling to more-distant specialists.
\end{abstract}

\section{Key words}

disability $\bullet$ healthcare travel $\cdot$ availability $\bullet$ accessibility $\bullet$ urban space $\cdot$ principal component analysis

- Bydgoszcz • Poland

\section{Introduction}

This paper focuses on the daily intra-urban mobility of disabled people in relation to visits to healthcare facilities, and as viewed from the perspective of social theory. People in possession of a legal certificate confirming disability, in accordance with Polish law, are compared with non-disabled counterparts from the same households treated as a reference category. This is in line with the statement that "the problems of the immobile socially excluded should not be analysed in isolation from the mobile included" (Preston \& Rajé 2007: 160).

To achieve the outlined research goal, the authors determined the architectural availability of healthcare facilities, studied accessibility among different transport micro-areas of the city, determined the main directions to flows among disabled and non-disabled members of the same households, and finally identified selected groups of features responsible for the daily movements engaged in by the two social categories. A brief literature review is first offered. 


\section{Literature review}

Since the body of geographical research into disability is now substantial, and has been reviewed elsewhere (Golledge 1993, 1997; Gleeson 1996, 1997, 1999; Imrie 1996a, b, 2000; Butler \& Bowlby 1997; Chouinard 1997; Park et al. 1998; Butler \& Parr 1999; Thomas 1999; Kitchin 2000, 2001; Anderson 2001; Hall \& Kearns 2001; Hall et al. 2002; Valentine 2003; Hall 2004; Philo \& Metzel 2005; Smith 2005; Imrie \& Edwards 2007; Crooks et al. 2008; Taylor \& Józefowicz 2012a, b), there is no need to analyse it here. Suffice it to say that research reported in the literature over the last twenty years or so is seen to represent tremendous progress when it comes to the extending of knowledge on disability, in a variety of different geographical settings. Specialisation is therefore necessary, and in this research we have selected to focus on mobility of disabled people, and their access to facilities, in urban space in particular.

This interest is justified by the fact that research into the mobility of the disabled (as compared to, say, the elderly) is in an absolute minority, not only in Poland. Moreover, since the majority of the research that does exist is rooted in social theory, it is founded upon qualitative methods in the main (Hall \& Kearns 2001; Brown \& Boardma 2011), there being a large number of papers taking such an approach. In contrast, very little attention has in fact been paid to the application of quantitative or model-based analyses (Matthews et al. 2003; Casas 2007; Schmöcker et al. 2008; Taylor \& Józefowicz 2012a, c).

The focus thus far has been on badly-designed infrastructure as a reason for limited mobility among the disabled (Gałkowski 1999; Gorzycka 1999; Imrie 2000; Grabowska-Pałecka 2004; Józefowicz 2006, 2007; Clarke et al. 2011), as well as on disability encouraging an unwillingness to travel (Oxley \& Richards 1995), or on the travel experiences and needs characterising the mobility-impaired (Hine \& Mitchell 2001). Porter (2000) has analysed the local trips taken by disabled people, and their access to means of transport. An important problem seen to restrict accessibility reflects the social barriers erected against certain social groups in public space (Casas et al. 2009), while legal obstacles to available healthcare for disabled people can be of an equally discriminatory nature (Yee \& Breslin 2010).

Gant (1992: 88) "identifies the different needs of the home-based disabled and presents a simplified user-based model" for customised transport services. Next, he examines the pedestrianisation of town centres, against the mobility and movement patterns of disabled persons, identifying contrasts relating to health circumstances and degree of mobility impairment (Gant 1997a, b). Likewise, Shopmobility schemes which have affected personal mobility, influenced accessibility and determined levels of personal comfort of disabled people, jointly with community and public transport services, have attracted the attention of researchers (Gant \& Smith 1998; Gant 2002). In turn, a promising pilot instrument for assessment of public bus transport accessibility has been developed by Iwarsson et al. (2000).

In the mid-1990s, Powell (1995) reviewed spatial work on access to healthcare, concluding that the contribution made by geographers is being very much ignored. However, such neglect can hardly be seen to exist anymore, in the wake of a vast increase in the number of studies that have been carried out on accessibility and the utilisation of healthcare among disabled people. Healthcare has been researched in relation to mental health services (Parr 1997), family planning services (Anderson \& Kitchin 2001; Trani et al. 2011), reproductive and maternity services (Trani et al. 2011), the treatment of chronic illnesses (Crooks \& Chouinard 2006), health and rehabilitation facilities (Urbanowicz \& Burda-Świerz 2006), and preventive health care (Clarke et al. 2011), to name but a few. Also subject to some analysis are related services, such as hospitality for guests with mobility impairments (Grady \& Ohlin 2009), or access to preschool special education for children with developmental disabilities (McManus et al. 2011) - not to mention the general (not disabled-only) utilisation of, and geographical access to, health services in Britain (Hine \& Kamruzzaman 2012).

\section{Study area, sample and methods}

The study area is Bydgoszcz, Poland's eighth largest city, which is inhabited by c. 373,000 people. From the point of view of the analysis of daily mobility and accessibility, the overall city area $\left(174.5 \mathrm{~km}^{2}\right)$ has been divided into 110 transport micro-areas (mikrorejony), first distinguished by researchers of the Bydgoszcz ATR Academy in 1995. In general, intensively built-up areas are divided finely, while extensively-developed areas are included within a few large units (Fig. 1).

The majority of data are from inventory research of healthcare facilities adapted for 


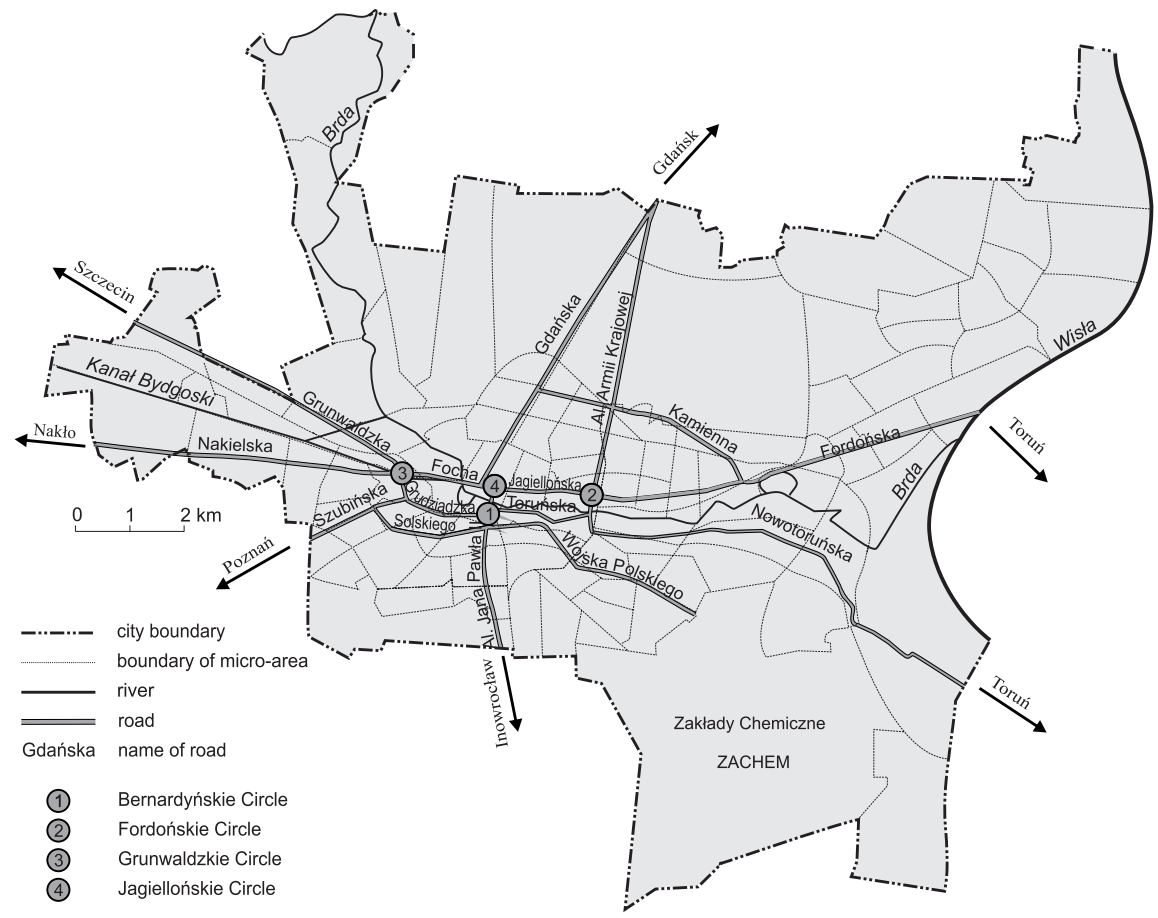

Figure 1. The study area: the city of Bydgoszcz.

disabled people, and from authors' standardised interviews carried out in mid-2008, the respondents being disabled working adults (450 altogether) and, for comparative purposes, 150 nondisabled members of the same households. Employees enjoying 'protected work'1 status in the city of Bydgoszcz were treated as the basic group. Therefore, the sample ${ }^{2}$ of $1.3 \%$ refers to the working disabled (as opposed to all disabled), a reasonable hypothesis, borne out by the facts, being that individuals within this sub-group of the wider group are less impaired than average. Indeed, nearly half of the sample experience only a slight degree of impairment. No fewer than 35\% of the respondents have problems with moving, while more than $31 \%$ have impairment of a multi-organ nature. Over one-third of the disabled use one orthopaedic device or another, be this crutches (over 22\%) or wheelchairs (over 11\%).

\footnotetext{
${ }^{1}$ Legal term coined for work employing people with disabilities in especially adjusted posts, creating particular conditions for the job, for healthcare and for rehabilitation. In turn, jobs with such a status enjoy some financial preferences under Polish law.

${ }^{2}$ Due to shortfalls in official statistics, snowball sampling has been applied in data collecting.
}

Orthopaedic devices are in general used more frequently (in over $64 \%$ of cases) by persons with substantial impairment. Among respondents with moderate impairment, every tenth person moves around using a wheelchair, while more than 25\% need crutches or walking sticks. Over $75 \%$ of disabled people with slight impairments do not use crutches or a wheelchair. Males are more likely than females to use orthopaedic devices to enable them to move.

The methods applied are well known to geographers. The research on spatial interaction and the accessibility of a given micro-area in relation to all other micro-areas makes use of the general model of potential given by:

$$
V_{i}=k\left(M_{j} / d_{i j}\right)
$$

where:

$V_{i}$ - the potential in micro-area $i$, expressed as a percentage of the total for the city,

$k$ - a constant (average size of interaction - number of trips per person),

$M_{j}$ - the mass (number of trips to micro-area $j$ from other micro-areas),

$d_{i j}$ - the real travel time distance between micro-areas $i$ and $j$. 
Principal component analysis has also been used in isolating the most important (of the 32) variables shown to influence the daily mobility of the disabled to healthcare facilities. Principal components should explain above $5 \%$ of the total variation. Varimax rotation and an interpretation of components on the basis of coefficients of determination have been applied.

\section{Results}

State of health and the meeting of medical requirements are the basic factors determining the functioning of disabled people in society, or else at times their marginalisation. It is for this reason that movements to healthcare establishments are of particular importance to this social category. The existence of multi-organ dysfunctions necessitates cyclical medical consultancies (Ostrowska et al. 2001). However, access to healthcare depends i.a. on principles of financing. According to Ostrowska et al. (2001), the healthcare reform of 1999 further hindered access to specialist doctors for disabled people, to say nothing of the way it encouraged pharmacies to commercialise . $^{3}$.

Daily mobility for healthcare purposes, on the part of the disabled, is analysed jointly with the architecture of facilities supplying medical services under the National Health Fund (Narodowy Fundusz Zdrowia; NFZ).

\section{The architectural availability of healthcare facilities}

The city of Bydgoszcz can boast 102 health establishments and 139 pharmacies in total (as of 2008). Within the first group, 46 specialist clinics (ośrodki zdrowia) and local clinics (przychodnie) have been considered by the analysis of architectural availability and accessibility. In these establishments there are surgeries of all doctors providing services within the NFZ. A majority of healthcare facilities are partly available to disabled people (Tab. 1).

Nearly $35 \%$ of facilities have a good level of adjustment, while $24 \%$ are only poorly adjusted to

\footnotetext{
${ }^{3} \mathrm{An}$ accurate characterisation of the public healthcare system in Poland in the early 1990s is provided by Millard (1995). Since then the system has been reformed several times; nevertheless, its main weaknesses, i.a. financial constraints, poor organisation, fragmentation, and pathological state-private symbiosis, have remained.
}

Table 1. Degree of adjustment of healthcare facilities in the city of Bydgoszcz.

\begin{tabular}{|l|c|c|c|}
\hline \multirow{2}{*}{ Adjustment } & \multirow{2}{*}{$\begin{array}{c}\text { Features } \\
\text { complying }\end{array}$} & \multicolumn{2}{|c|}{ Facilities } \\
\cline { 3 - 4 } & & number & $\%$ \\
\hline Good & $\geq 80 \%$ & 16 & 34.78 \\
Partial & $50-79 \%$ & 19 & 41.31 \\
Poor & $<50 \%$ & 11 & 23.91 \\
\hline Total & & 46 & 100.00 \\
\hline
\end{tabular}

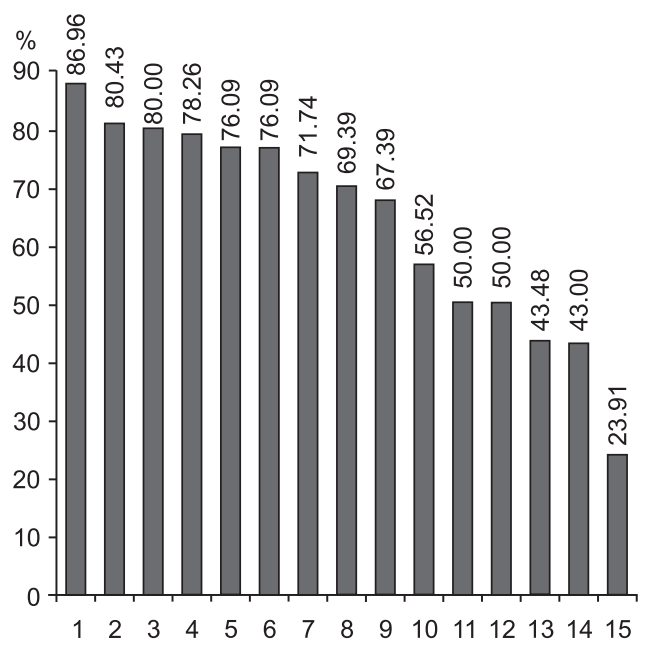

Figure 2. Adjustment of healthcare facilities to the needs of disabled people, in line with relevant architectural features: 1 - thresholds, 2 - paths, 3 - doormats, 4 - signage, 5 - banisters, 6 - manoeuvring areas, 7 - ramps, 8 - toilets, 9 - furniture, 10 - colours, 11 - parking areas, 12 - doors, 13 - lifts, 14 - kerbs, 15 - sounds.

the needs of this social category. The most major difficulties apply in the case of sounds (just 24\% of buildings possess such conveniences (Fig. 2)). More than $40 \%$ of all objects have lifts and lowered kerbs. In the case of older buildings there are some limitations where the mounting of lifts is concerned. In every second object, a disabled person with moving problems encounters a barrier in the form of non-adjusted front doors and a lack of convenient parking areas. People with movement dysfunction can reach the majority of small specialist clinics (poradnie), thanks to the existence of ramps, manoeuvring areas, adjusted thresholds and doormats. The latter, together with large signage, are important for the visually impaired.

A majority of healthcare establishments providing medical services within the NFZ system are located in the city centre. This is probably due to 
the fact that some services, especially specialist ones, are planned for the inhabitants of a whole region, not just inhabitants of the city. However, among the latter, only one facility can be treated as properly adjusted for disabled people, while others are partly-or even poorly-adjusted. Nevertheless, in the near-vicinity of the city centre, there are three facilities well-equipped for the disabled. Districts located further away from the centre have at least one specialist clinic. By-and-large these facilities are well- or partly-adjusted to the needs of disabled people. Poorly-adjusted local clinics (przychodnie) are present in the centre, as well as on the outskirts of the city.

Among the disabled declaring that they make use of healthcare, $54.42 \%$ possess a permanent certificate of disability. Nearly every second person takes advantage of medical help once a month, over $30 \%$ consult a doctor several times a year, and $17 \%$ pay daily or weekly visits to a doctor (Fig. 3).

In no way is the frequency of visits correlated with the degree of impairment. All time-sections display an even distribution where the degree of impairment of disabled people is concerned. Almost all the disabled people studied commute to healthcare from their place of residence, with less than $8 \%$ travelling there directly from places of work, and $1.19 \%$ doing so from homes of their families. The average travel time is c. 21 minutes.

\section{General modal split for journeys to healthcare facilities}

Out of a total of 450 disabled respondents, 419 declare usage of medical services. The coefficient of daily mobility (ratio of number of journeys to number of inhabitants researched) for healthcare trips taken by people with disabilities is thus 0.93 , as compared with 0.57 in the case of their counterparts without disabilities.

Aldred and Woodcock (2008: 492) write that (on the UK example) "for many disabled people private cars are the only form of accessible transport, and restrictions on car usage are negative for disabled people"4. A similar statement regarding the hegemony of the car was given much earlier by Morris and Snelson (1994). In our case, however, such reliance on cars is not seen, and walking and public transport (buses and trams) play important roles in the daily mobility of the disabled. Particularly positive is the major role played by walking (and the much more limited role played by cycling) among disabled people, though other active or green transport is not used (Tab. 2, Fig. 4). Walking is presumably connected first and foremost with a visit to a doctor in a nearby local clinic or small

\footnotetext{
${ }^{4}$ This does not imply that Aldred \& Woodcock (2008) agree with, or are supporters of, the above-mentioned British situation. On the contrary, they are critiquing this viewpoint, as is clearly visible in their paper.
}

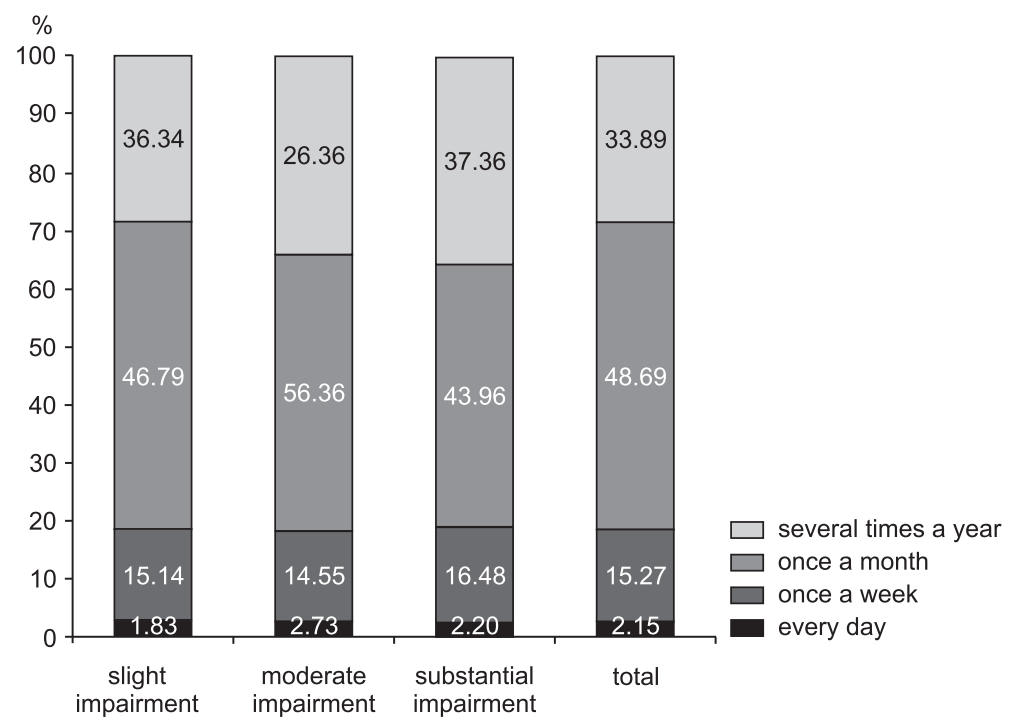

Figure 3. Frequency of movements to healthcare facilities made by disabled people, as categorised by degree of impairment. 
specialist clinic. Although a car is also made use of frequently, mainly in 'passengering', the use of public transport should be stressed. It can be supposed, that financial factors are at work here, with rather few disabled people in the city being able to afford to purchase and maintain a car.

Table 2. Modal split for journeys to healthcare facilities.

\begin{tabular}{|l|c|c|}
\hline \multicolumn{1}{|c|}{$\begin{array}{c}\text { Main mode } \\
\text { by distance travelled }\end{array}$} & $\begin{array}{c}\text { Disabled } \\
\text { persons (\%) } \\
N=419\end{array}$ & $\begin{array}{c}\text { Non-disabled } \\
\text { persons (\%) } \\
\text { N=86 }\end{array}$ \\
\hline Walk & 24.11 & 52.32 \\
Bicycle & 2.15 & 1.16 \\
Motorcycle & 0.72 & 0 \\
Car (as driver) & 16.95 & 23.25 \\
Car (as passenger) & 31.50 & 11.62 \\
Tram & 4.76 & 1.16 \\
Bus & 15.51 & 8.17 \\
Minibus & 0 & 1.16 \\
Taxi & 4.30 & 1.16 \\
\hline Total & 100.00 & 100.00 \\
\hline
\end{tabular}

often by the able-bodied than the disabled. Overall this denotes more sustainable transport use in the case of the disabled.

\section{Accessibility of transport micro-areas and journeys to healthcare facilities}

The value for the gravity potential of micro-area $i$ is a measure of its accessibility from all other microareas. A minority $(46.36 \%)$ of transport microareas reveal some interaction (positive value for potential) in the form of journeys made to healthcare facilities by disabled people (Tab. 3).

The highest value for gravity potential $(14.40 \%)$ is observed in the case of the southcentral micro-area, this featuring one of the largest multi-specialist medical establishments - the University Hospital (Fig. 5). As well as a dozen or so wards, this runs 40 small specialist clinics, and provides primary care as well. The hospital

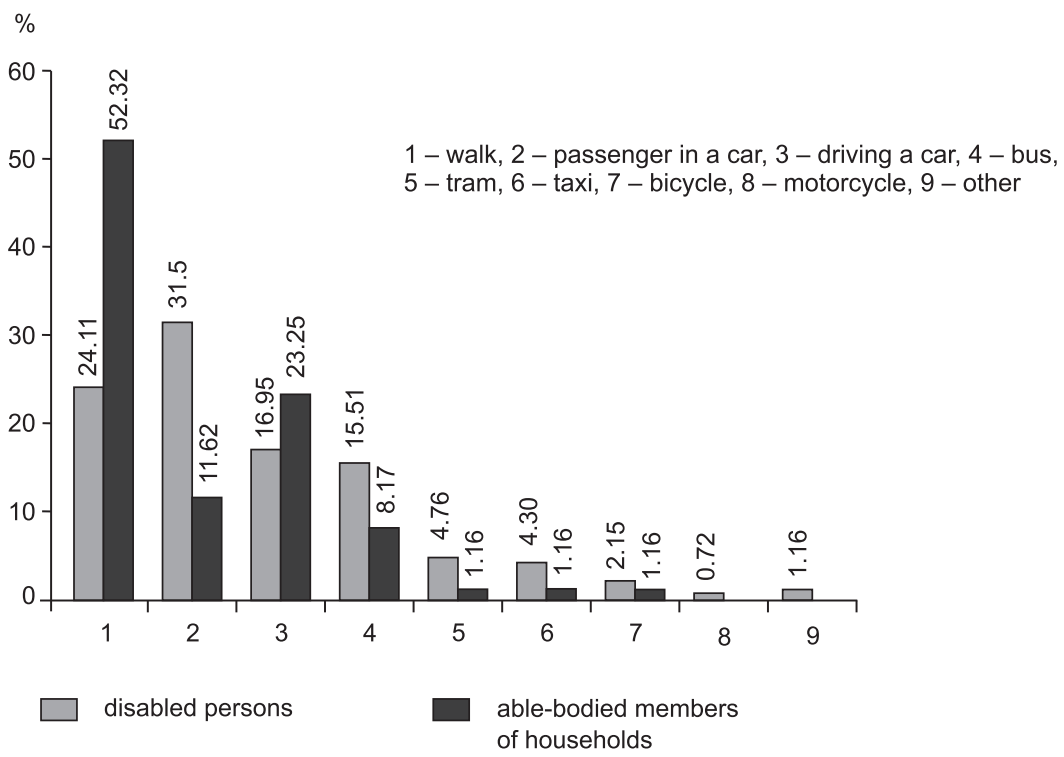

Figure 4. Modal split for journeys made to healthcare facilities by disabled people and able-bodied members of their households.

When the disabled people and their able-bodied counterparts in Bydgoszcz are compared, differences in the mode of transport used for journeys to healthcare facilities are very visible. Walking and car-driving are resorted to much more frequently by non-disabled persons than by their disabled counterparts. All the other modes are used less is a facility well-adjusted to the needs of disabled people. Out of all the disabled respondents, more than $15 \%$ declare that they pay visits to doctors practising there. An absolute majority (59.42\%) of those studied are people with moving problems, and every sixth has multi-organ impairments. Almost half of the respondents access the Uni- 
versity Hospital by car, and need escorting (by a driver). Despite a disfavoured location from the point of view of the road network, the Hospital enjoys relatively good connections within the urban transport system. What seems to be of even greater importance is that the good quality of medical services causes the facility to be chosen most often by the disabled.

Table 3. Micro-areas and their potential for journeys to healthcare facilities by disabled people.

\begin{tabular}{|l|r|r|}
\hline \multirow{2}{*}{$\begin{array}{c}\text { Value for potential } \\
\text { (\%) }\end{array}$} & \multicolumn{2}{|c|}{ Micro-areas } \\
\cline { 2 - 3 } & number & \multicolumn{1}{c|}{$\%$} \\
\hline 0 & 59 & 53.64 \\
$0.1-1.99$ & 38 & 34.54 \\
$2.0-3.99$ & 6 & 5.46 \\
$4.0-5.99$ & 4 & 3.64 \\
$6.0-9.99$ & 2 & 1.82 \\
$10.0-14.4$ & 1 & 0.91 \\
\hline Total & 110 & 100.00 \\
\hline
\end{tabular}

The area chosen second most often is the citycentre core. Respondents travelling to the centre visit two specialist clinics that are, however, facili- ties poorly adjusted to the needs of the disabled. This micro-area is located near to a main transport node that is a junction of several tram and bus lines. It is also the location of a substantial firm employing disabled people and possessing its own oculist industrial clinic.

In the next micro-area with a high value for gravity potential there are three medical centres, all poorly-adjusted for patients. The above mentioned results suggest availability from the architectural point of view is not of primary importance where the use of medical services by the disabled is concerned.

Since interaction with commuting to doctors does not only take place in micro-areas providing services within the NFZ system, it may be presumed that the disabled make use of private doctors, too. There are also small differences in behaviour between males and females as regards journeys to healthcare facilities.

The results of the accessibility analysis carried out for non-disabled members of the same households show distinct differences in respondents' behaviour. In the case of a majority (76.33\%) of the micro-areas, there is no interaction (Tab. 4).

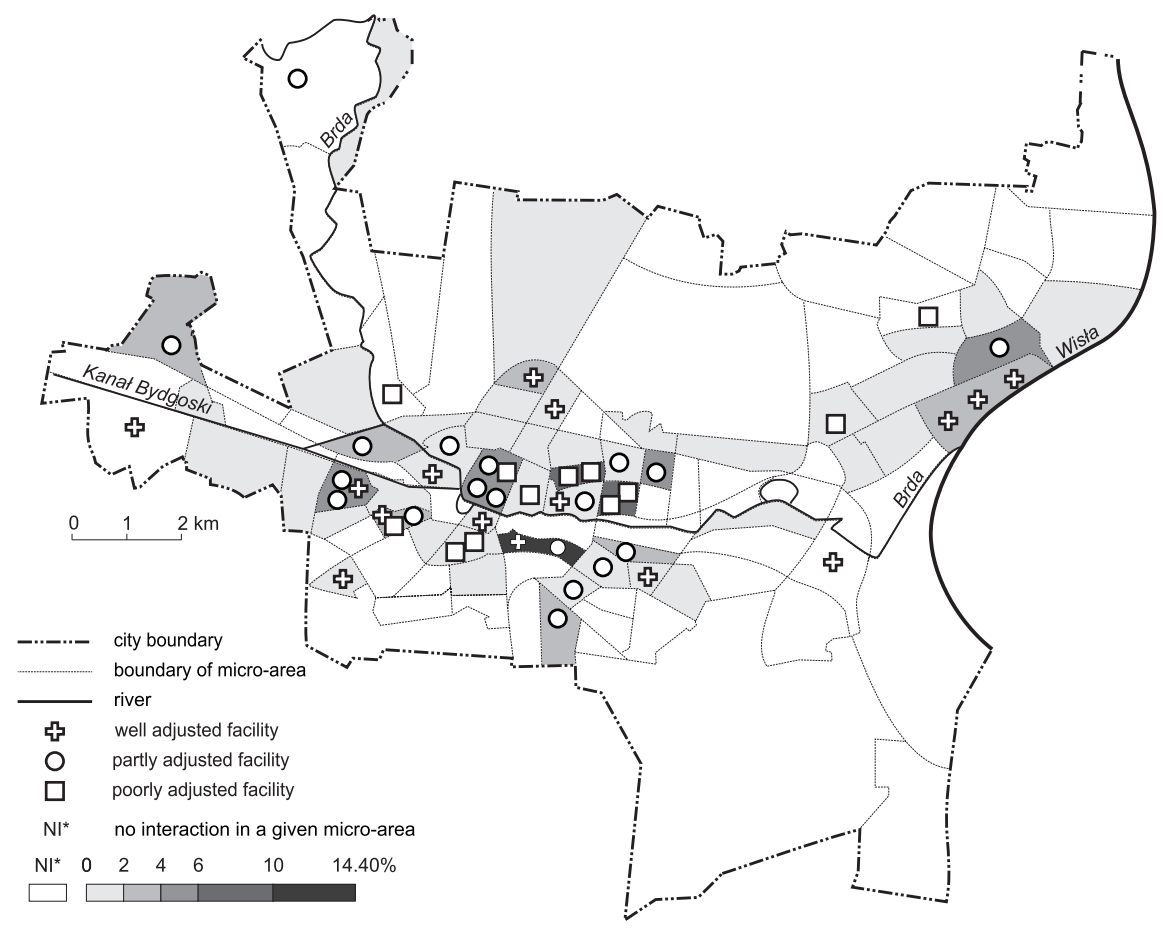

Figure 5. Gravity potential - journeys made to healthcare facilities by disabled people. 
Table 4. Micro-areas and their potential values for journeys to healthcare facilities taken by able-bodied members of households.

\begin{tabular}{|l|r|r|}
\hline \multirow{2}{*}{\begin{tabular}{c} 
Value for potential \\
\multicolumn{1}{c|}{$(\%)$}
\end{tabular}} & \multicolumn{2}{|c|}{ Micro-areas } \\
\cline { 2 - 3 } & (number) & $(\%)$ \\
\hline 0 & 84 & 76.36 \\
$0.1-1.99$ & 10 & 9.10 \\
$2.00-3.99$ & 7 & 6.37 \\
$4.00-5.99$ & 2 & 1.82 \\
$6.00-7.99$ & 2 & 1.82 \\
$8.00-15.46$ & 5 & 4.55 \\
\hline Total & 110 & 100.00 \\
\hline
\end{tabular}

Within the remaining 26 micro-areas, the best accessibility (15.46\%) for the non-disabled is enjoyed by the SW micro-area relatively close to the city centre (Fig. 6). Altogether, there are four medical centres, including two that are well-adjusted facilities and the other two partly-adjusted facilities. It is of some interest that health centres relatively positively adjusted have not been visited particularly often by the disabled. This is probably due to a poor urban public transport location which is, however, no barrier in the case of able-bodied respondents.

The second micro-area with a high value for the potential for journeys by the able-bodied is that embracing University Hospital, as mentioned above. The micro-area coming top for the disabled receives a much lower value for potential $(7.63 \%)$ in the case of the non-disabled members of households. They also commute to the microarea of the Military Hospital with Polyclinic, while one of the goals for the disabled, this is not of special interest to non-disabled respondents. This may suggest that able-bodied people consult general practitioners (called 'family doctors' in Poland) more frequently, rather than the specialist doctors more often dealing with disabled patients.

\section{Trips within micro-areas and passenger flows}

Journeys between micro-areas represent one issue, while another concerns what analysis of intra-micro-area trips and their spatial distribution reveals about differences between the two categories researched. Among disabled people, within-area trips are observed in the case of 18 micro-areas, thus representing $35.29 \%$ of all interaction areas (Fig. 7). In the case of able-bodied members of households this is more than every second micro-area (53.84\%) with interaction (Fig. 8).

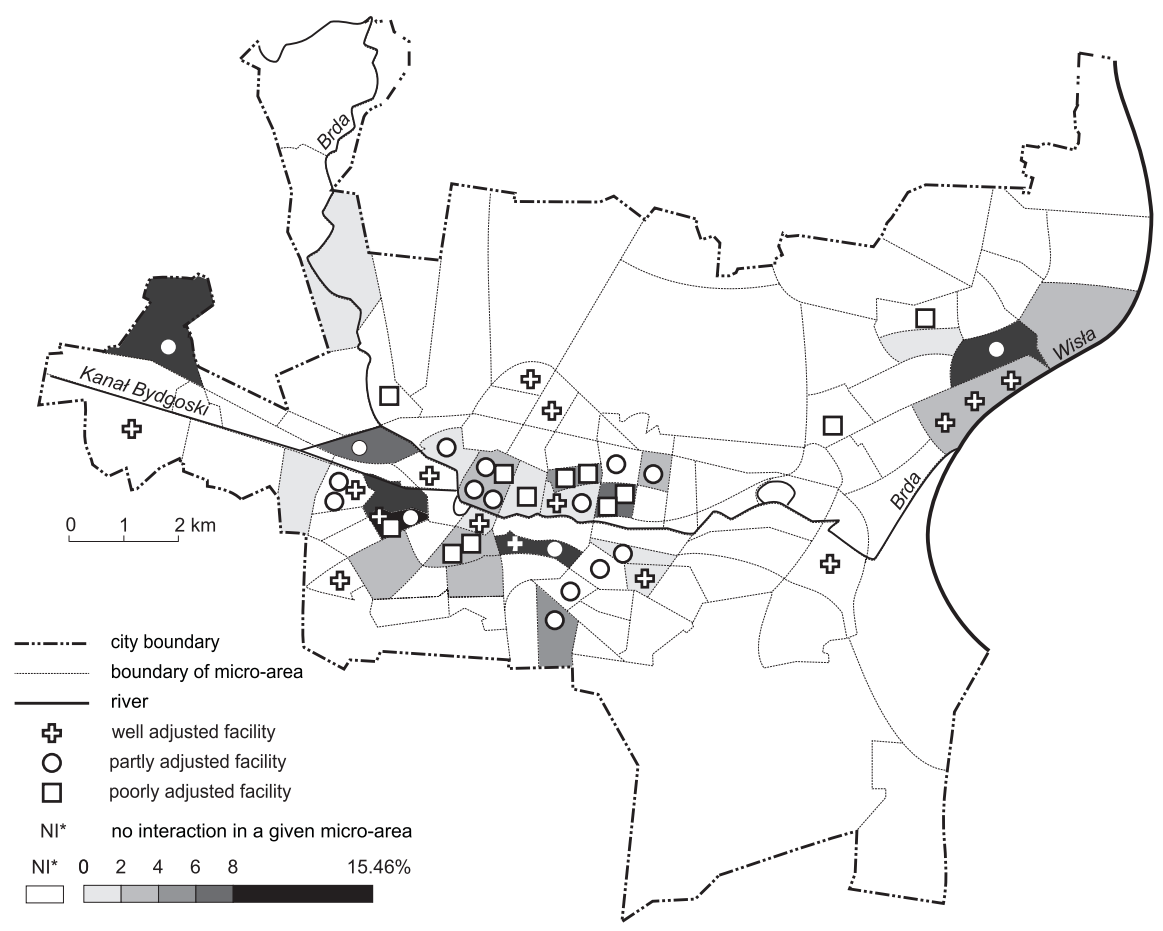

Figure 6. Gravity potential - journeys made to healthcare facilities by able-bodied members of (the same) households. 


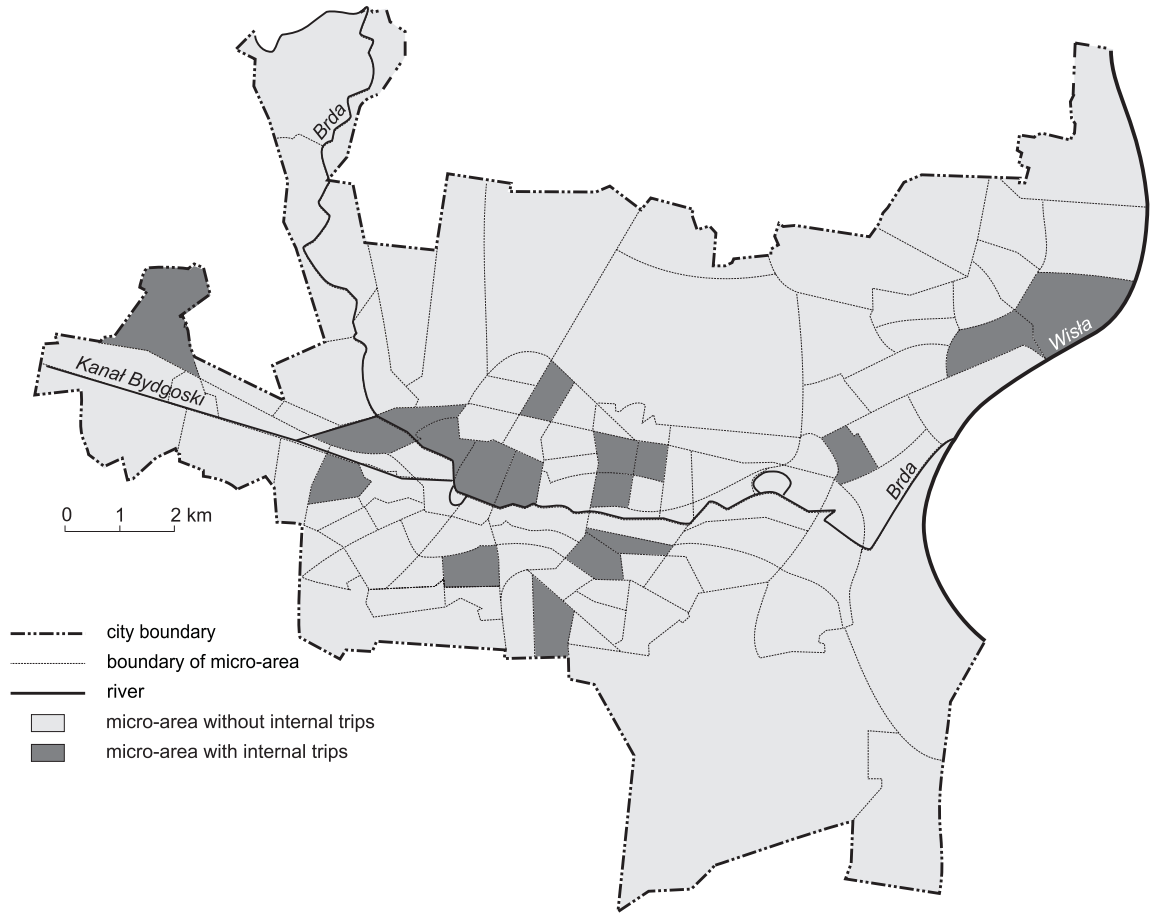

Figure 7. Intra-micro-area journeys made to healthcare facilities by disabled people.

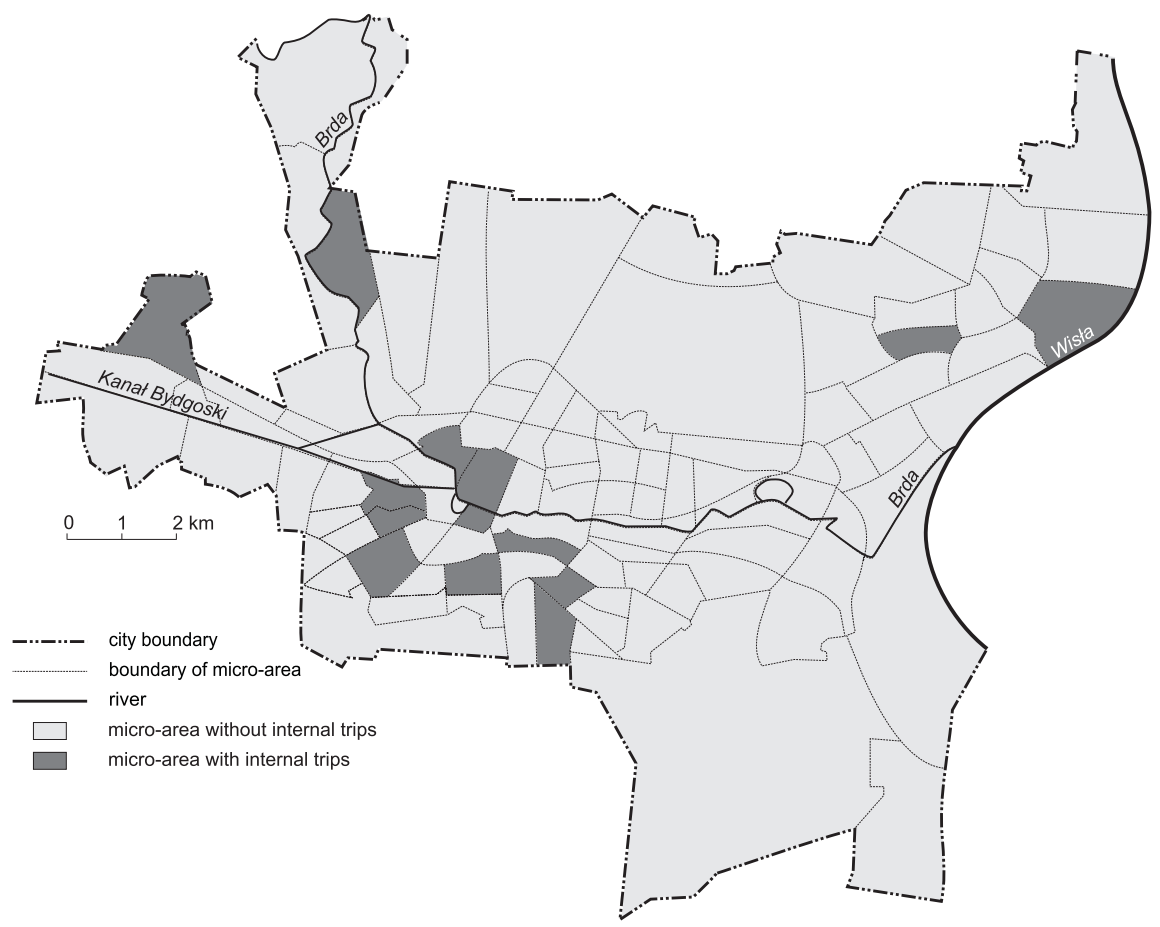

Figure 8. Intra-micro-area journeys made to healthcare facilities by able-bodied members of (the same) households. 


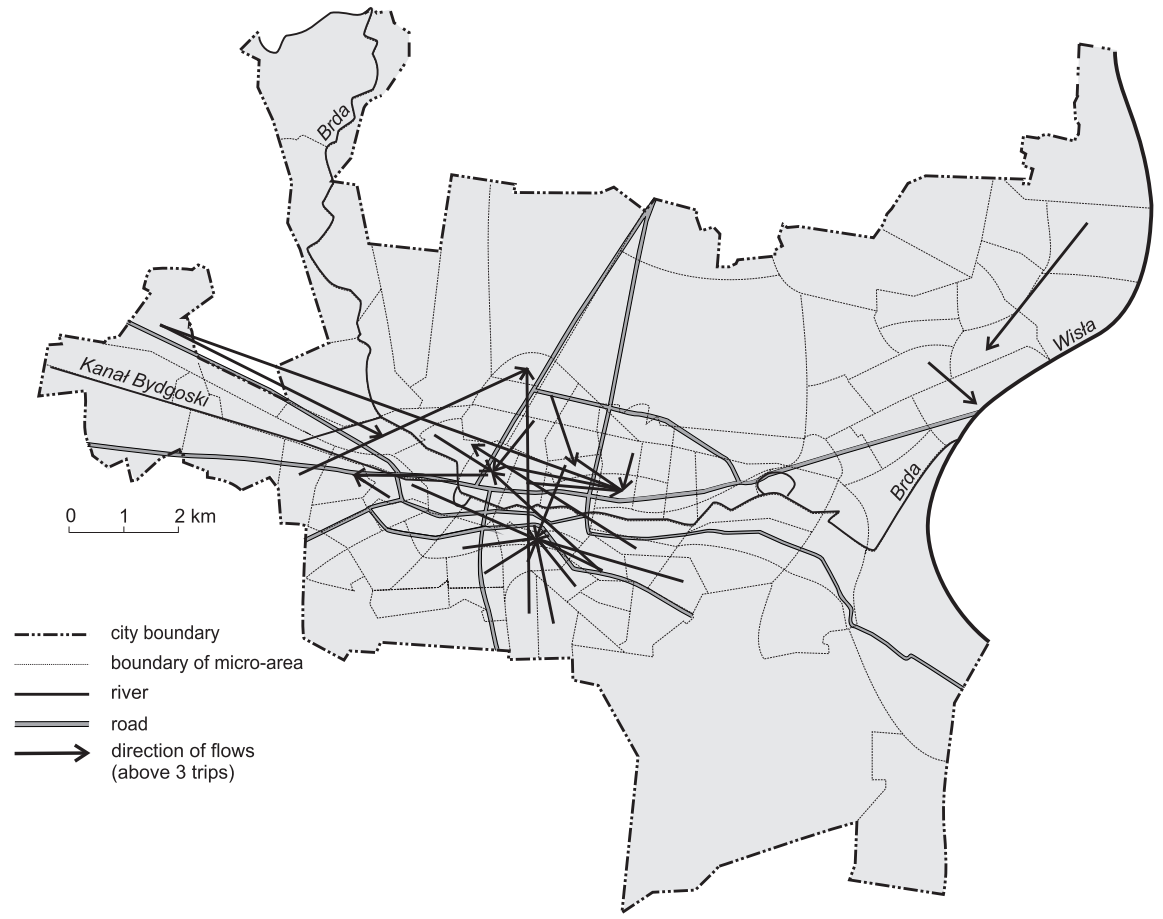

Figure 9. Passenger flows - journeys made to healthcare facilities by disabled people.

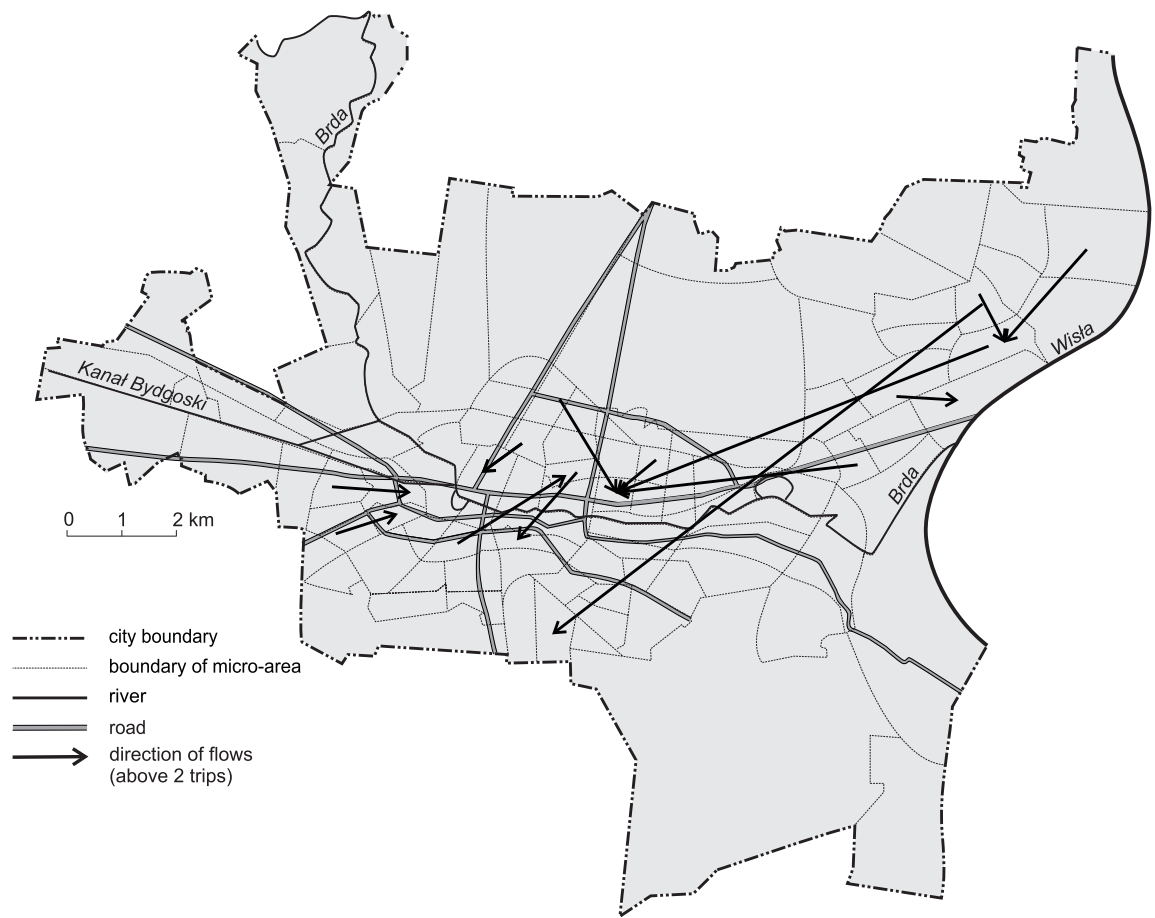

Figure 10. Passenger flows - journeys made to healthcare facilities by able-bodied members of (the same) households. 
By-and-large, trips within micro-areas embrace centrally-located parts, as well as the outskirts of the city, without a clear spatial distribution pattern.

However, a characteristic feature for disabled people is the lack of internal trips within microareas featuring large multi-specialist healthcare establishments, such as University Hospital and/or the Military Hospital with Polyclinic. This may suggest that respondents look for the help of general practitioners and specialist doctors in the vicinity of their place of residence, rather than further away.

Able-bodied members of households are also more likely to choose health facilities in the environs of their places of residence - a fact that can be linked with the frequent use made of primary care in this case, as well as the way in which the healthcare system is organised (with a relatively large number of GPs spread widely, and only a much smaller number of specialists mainly offering their services in large units).

Passenger flows for the two categories show greater differentiation, however. In the case of disabled people, it is possible to discern a concentration of destinations in just several micro-areas (Fig. 9). The most common transfers are towards the University Hospital, Military Hospital and oculist industrial clinic already referred to. Disabled persons more often choose a healthcare facility at a distance from the place of origin $(78.58 \%$ of journeys go beyond neighbouring micro-areas).

In the case of the non-disabled members of households, such a concentration of passenger flows into a few micro-areas is not to be observed (Fig. 10). Only two micro-areas focus flows from more than one area, all others being directed to a range of locations across the city. Every second able-bodied person is seen to have chosen a health facility located close to the micro-area of origin - a fact that may reflect the choice of the nearest primary care facility, albeit still beyond the immediate home area. If advantage is to be taken of the services of a more specialised doctor, then access to a more distant facility will be required.

\section{Characteristics of respondents travelling to healthcare facilities}

Principal components analysis has been used in extracting the group of original variables influencing the daily movements of disabled people and their non-disabled counterparts from the same households. This method provides for the relative- ly full reduction of data, and for their transformation into new orthogonal variables (with a simultaneously low level of information loss).

Our analysis involving disabled people provided for the extraction of three principal components (in accordance with the $5 \%$ criterion of variance explained). Together, these explain $82.51 \%$ of total variability (Tab. 5).

Table 5. Eigenvalues for the three principal components extracted for the journeys to healthcare facilities made by disabled people.

\begin{tabular}{|c|c|c|c|c|}
\hline $\begin{array}{c}\text { Compo- } \\
\text { nent }\end{array}$ & $\begin{array}{c}\text { Eigen- } \\
\text { value }\end{array}$ & $\begin{array}{c}\% \\
\text { of total }\end{array}$ & $\begin{array}{c}\text { Accu- } \\
\text { mulated } \\
\text { eigen- } \\
\text { value }\end{array}$ & $\begin{array}{c}\text { Accumu- } \\
\text { lated } \% \\
\text { of total } \\
\text { variance } \\
\text { explained }\end{array}$ \\
\hline I & 22.82001 & 71.31253 & 22.82001 & 71.31253 \\
II & 1.96552 & 6.14224 & 24.78553 & 77.45477 \\
\hline & 1.61890 & 5.05906 & 26.40443 & 82.51384 \\
\hline
\end{tabular}

The first component accounts for $71.31 \%$ of the variance, and correlates significantly with 15 original variables, while further components account for a much smaller part of the variance (Tab. 6).

Taking into account the highest values of the determination coefficient, we can say that the first component characterises well-educated people $\left(P_{8}: 0.73\right)$ with a temporary certificate of disability $\left(P_{12}: 0.73\right)$ and multi-organ conditions $\left(P_{21}: 0.70\right)$, having moderate or slight impairment. Besides disabled people with multi-organ conditions, account can be taken of respondents with moving difficulties, with hearing conditions and using a wheelchair. Among mobility variables, it is that of disabled respondents being car passengers that achieves the highest value $\left(P_{29}: 0.63\right)$.

The spatial distribution of the first principal component (Fig. 11) presents a majority $(77.27 \%)$ of micro-areas that have values below zero, which are spread all over the city. The highest value noted for the first component is in the micro-area embracing the University Hospital. Proximity to the city centre and convenient parking places justify a choice of transport mode. The second highest value is also in the central micro-area embracing several medical establishments. However, every fifth micro-area with positive values is located in the outskirts, near the city limits.

The second principal component accounts for $6.14 \%$ of the variance (Tab. 5) and is correlated significantly with one variable only - disabled 
Table 6. Classification of variables for principal components extraction by the journeys of disabled people to healthcare facilities (arranged in line with values for loading).

\begin{tabular}{|c|c|l|c|c|}
\hline Component & Variable & \multicolumn{1}{|c|}{ Variable characteristic (number) } & $\begin{array}{c}\text { Component } \\
\text { loading }\end{array}$ & $\begin{array}{c}\text { Coefficient } \\
\text { of determination }\end{array}$ \\
\hline I & $P_{8}$ & respondents with higher education & 0.85559 & 0.73 \\
& $P_{12}$ & respondents with temporary certificate of disability & 0.85197 & 0.73 \\
& $P_{21}$ & respondents with multi-organ conditions & 0.83426 & 0.70 \\
& $P_{10}$ & respondents with moderate impairment & 0.83322 & 0.69 \\
& $P_{3}$ & respondents of mobile working age (18-44 years old) & 0.82032 & 0.67 \\
& $P_{11}$ & respondents with slight impairment & 0.81841 & 0.67 \\
& $P_{23}$ & respondents using a wheelchair & 0.81012 & 0.66 \\
& $P_{14}$ & respondents with moving difficulties & 0.80811 & 0.65 \\
& $P_{29}$ & respondents - car passengers & 0.79455 & 0.63 \\
& $P_{7}$ & respondents with secondary education & 0.79123 & 0.63 \\
& $P_{1}$ & respondents - females & 0.78608 & 0.62 \\
& $P_{15}$ & respondents with hearing conditions & 0.77051 & 0.59 \\
& $P_{2}$ & respondents - males & 0.73530 & 0.54 \\
& $P_{24}$ & respondents not using orthopaedic devices & 0.73117 & 0.53 \\
& $P_{4}$ & respondents of non-mobile working age (females $45-59$, & 0.70857 & 0.50 \\
& & males 45-64 years old) & & \\
& $P_{27}$ & respondents travelling by motorcycle & 0.92293 & 0.85 \\
& $P_{16}$ & respondents with sight conditions & 0.885274 & 0.78 \\
& $P_{9}$ & respondents with substantial impairment & 0.857122 & 0.73 \\
& $P_{31}$ & respondents travelling by bus & 0.822073 & 0.68 \\
& $P_{5}$ & respondents with primary education & 0.802929 & 0.64 \\
& $P_{6}$ & respondents with vocational education & 0.780082 & 0.61 \\
& $P_{17}$ & respondents with cardiovascular system conditions & 0.713333 & 0.51 \\
& $P_{13}$ & respondents with permanent certificate of disability & 0.704316 & 0.50 \\
\hline \multirow{6}{*}{} & & & & \\
\hline
\end{tabular}

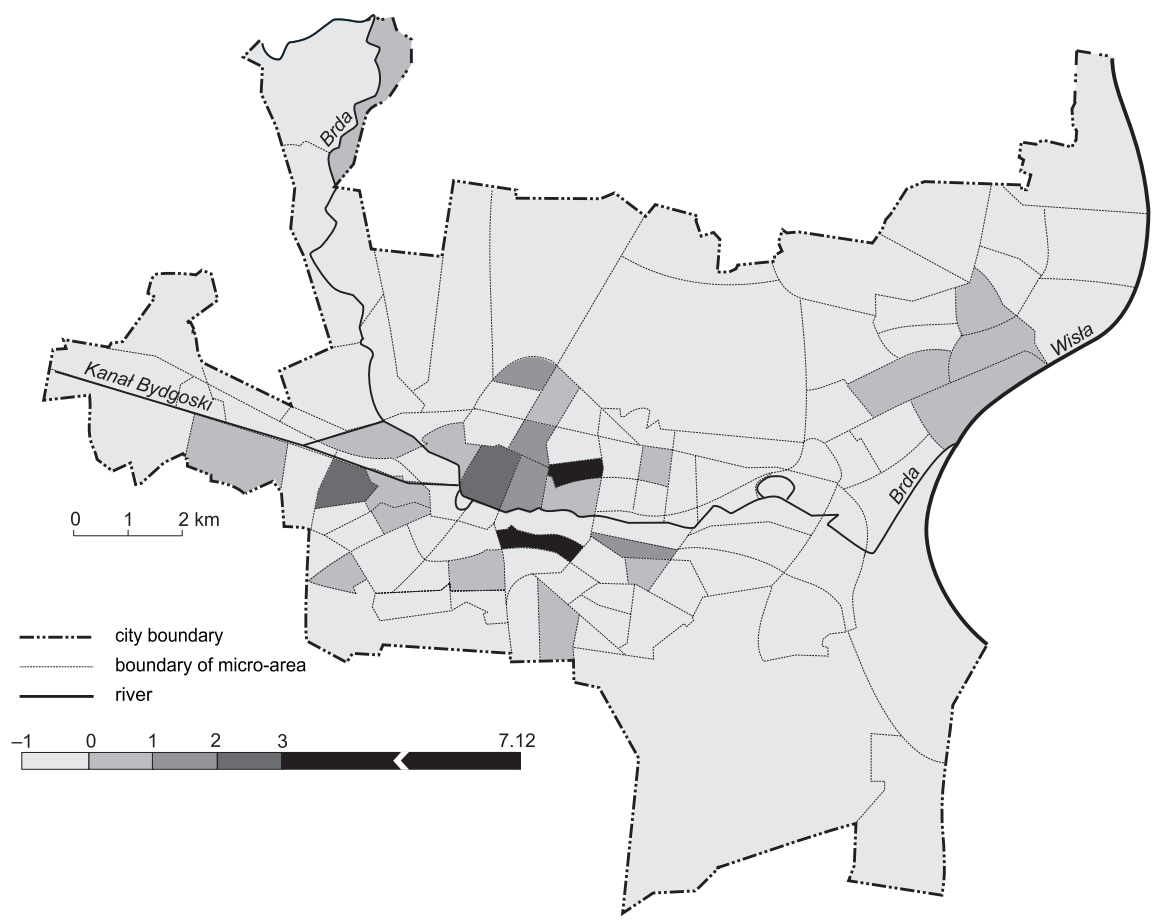

Figure 11. Spatial distribution - first principal component by the journeys made to healthcare facilities by disabled people. 
people travelling to healthcare facilities by motorcycle (Tab. 6). Just about $12 \%$ of micro-areas have positive values for the second component. Nevertheless, the difference between the lowest and highest value is 9.83 (the latter indicating the micro-area embracing the Military Hospital with Polyclinic). Finally, the third component accounts for above 5\% of the variance and characterises respondents with substantial impairment, poorly-educated, with sight conditions, and travelling by bus.

In the case of non-disabled members of households, 15 original variables describing daily mobility have been taken into account. In analysis, three principal components have been extracted, explaining $72.92 \%$ of total variability (Tab. 7 ).

Table 7. Eigenvalues for the three principal components extracted for the journeys to healthcare facilities made by non-disabled members of households.

\begin{tabular}{|c|c|c|c|c|}
\hline $\begin{array}{c}\text { Compo- } \\
\text { nent }\end{array}$ & Eigenvalue & $\begin{array}{c}\text { Share } \\
\text { of total } \\
(\%)\end{array}$ & $\begin{array}{c}\text { Accu- } \\
\text { mulated } \\
\text { eigenvalue }\end{array}$ & $\begin{array}{c}\text { Accumu- } \\
\text { lated \% } \\
\text { of total } \\
\text { variance } \\
\text { explained }\end{array}$ \\
\hline I & 7.759846 & 51.73231 & 7.75985 & 51.73231 \\
II & 1.838714 & 12.25809 & 9.59856 & 63.99040 \\
III & 1.339592 & 8.93061 & 10.93815 & 72.92101 \\
\hline
\end{tabular}

The first principal component with a value of $7.76 \%$ explains four times as much variability as the next one, and is correlated significantly with five original variables (Tab. 8). The highest values for coefficients of determination apply in the case of access to healthcare facilities $\left(P_{25}\right.$ and $\left.P_{32}\right)$. Thus, the first component characterises secondary-educated, able-bodied members of households walk- ing or travelling by taxi to healthcare. These are males of mobile working age.

As in earlier cases, the first principal component in a majority of micro-areas has negative values $(76.36 \%)$ or values close to zero $(17.27 \%$ less than one). Most (above 84\%) of the micro-areas with positive values are intra-urban, while just four of them are located close to the administrative boundary of the city (Fig. 12).

The highest value characterises the microarea located close to Fordońskie Circle (Fig. 1) and embracing the oculist clinic as well as general practitioners', none of these being adjusted to the needs of disabled patients. A majority of able-bodied respondents walk to healthcare facilities. The second value is that of a micro-area with the so-called 'West' medical centre, but the next one has no single public healthcare facility, which means respondents visiting private doctors. All the other micro-areas with positive values are located near the city centre, with one exception - the eastern city district of Fordon with several large local clinics.

The second component accounts for over $12 \%$ of the variance (Tab. 7), and correlates significantly with two original variables: respondents with primary education and their 'passengering' to healthcare facilities (Tab. 8). Within the spatial distribution of the second component, the highest value is that of the city centre core with three large healthcare establishments. The very concentration of micro-areas with higher values of the second component can be explained by relatively favourable accessibility vis-à-vis the urban road network.

And finally, the third principal component - explaining $8.93 \%$ of variability - only correlates

Table 8. Classification of variables for principal components extraction - journeys of non-disabled members of households to healthcare facilities (arranged in line with values for loading).

\begin{tabular}{|c|l|l|c|c|}
\hline \multirow{2}{*}{ Component } & Variable & \multicolumn{1}{|c|}{ Variable characteristic (number) } & $\begin{array}{c}\text { Component } \\
\text { loading }\end{array}$ & $\begin{array}{c}\text { Coefficient } \\
\text { of determination }\end{array}$ \\
\hline \multirow{2}{*}{ I } & $P_{25}$ & respondents moving on foot & 0.895167 & 0.80 \\
& $P_{32}$ & respondents travelling by taxi & 0.891860 & 0.80 \\
& $P_{7}$ & respondents with secondary education & 0.870344 & 0.76 \\
& $P_{2}$ & respondents - males & 0.788685 & 0.62 \\
& $P_{3}$ & respondents of mobile working age & 0.769797 & 0.59 \\
& $P_{5}$ & (18-44 years old) & 0.922820 & 0.85 \\
& $P_{29}$ & respondents with primary education & 0.878599 & 0.77 \\
& $P_{30}$ & respondents - car passengers & 0.847010 & 0.72 \\
& $P_{6}$ & respondents travelling by tram & 0.761588 & 0.58 \\
\hline
\end{tabular}




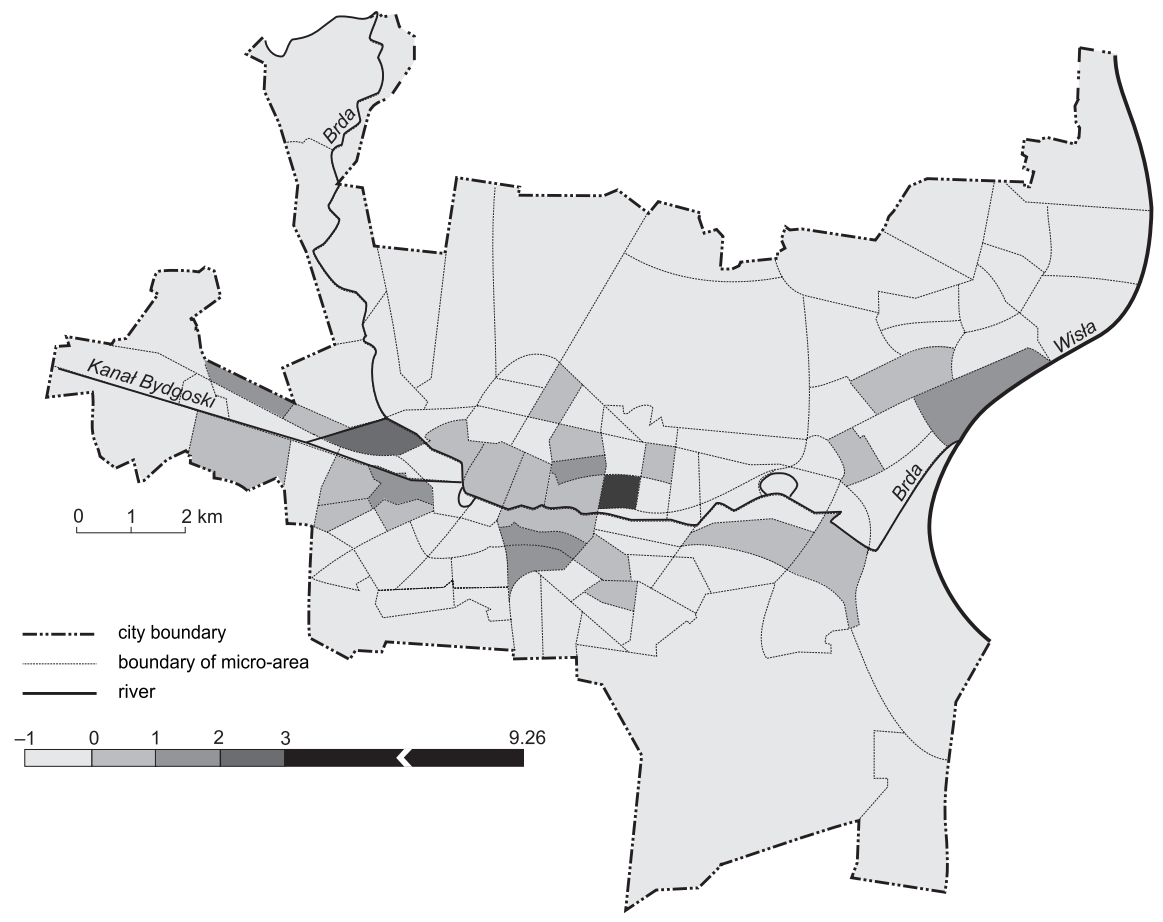

Figure 12. Spatial distribution of the first principal component - journeys made to healthcare facilities by able-bodied members of (the same) households.

significantly with the two original variables (Tab. 8). It describes poorly-educated, able-bodied people travelling to healthcare facilities by tram.

\section{Conclusions}

This study is limited to a geographically-defined sample in an urban setting. The fact that the intraurban daily mobility of people with disabilities and their able-bodied counterparts is a multidimensional phenomenon confirms the findings of earlier studies (Kitchin 1998; Kitchin \& Wilton 2000; Barrett et al. 2003; Yau et al. 2004; Filipek 2006; Barnes \& Mercer 2008). Overall, there are great differences between the two categories where healthcare provision is concerned. Disabled people show greater mobility in respect of healthcare than do their non-disabled counterparts, as is confirmed by values for coefficients of mobility. People with a certificate confirming disability in the eyes of the law do make much more frequent use of healthcare services, in line with what is commonly supposed. Moreover, place-awareness and placesensitivity (Kearns \& Moon 2002) seem to play an important role as regards healthcare provision for both categories of respondent.
One of the purposes of this study has been to verify the argument that architectural availability determines the spatial behaviour of disabled people. Just $24 \%$ of facilities are poorly-adjusted to the needs of disabled persons. Unlike cultural or sporting venues (Taylor \& Józefowicz 2012a, c), a majority of the facilities rendering services within the framework of NFZ healthcare are characterised by a good or moderate level of adjustment to the needs of disabled people. Nevertheless, this factor seems to be of secondary importance when access to healthcare is taken into account. Of much greater importance is, for example, the location of a facility as regards the public transport network.

In the case of accessibility, higher values for gravity potential are noted in micro-areas beyond the main transport axis, but relatively well-linked to the remaining parts of the city. Journeys of the disabled for healthcare purposes are connected with the locations of facilities in urban space. Since the urban transport pattern is of course created in line with the real needs of inhabitants, potential areas of greater destination flows should be well-connected with the remaining parts of the city. This is especially true in the case of large multi-specialist healthcare establishments (such as the University 
Hospital or the Military Hospital with Polyclinic): micro-areas embracing such facilities enjoy the best accessibility. Moreover, positive values for potential are observed in a further 19 micro-areas lacking public health service facilities, this thereby attesting to the intensive use also made of private doctor's surgeries and health centres.

There has been no confirmation of the idea that disabled people choose healthcare facilities located relatively close to the source (origin) of their journeys (usually their place of residence), or that socio-economic characteristics influence their mobility. Passenger flows to healthcare facilities rather show a visible focusing on micro-areas that embrace large, multi-specialist outlets, such as the University Hospital or the Military Hospital with Polyclinic, providing complex services. Disabled people prefer to commute further, and for longer, to establishments providing comprehensive medical services at a high level. Thus, 78.58\% of all journeys are to places fairly distant (at least further than the micro-area adjacent to the place of origin). The reasons for such a regularity may lay in the way the healthcare system is organised (with specialist doctors mainly providing their services in large establishments), as well as in care for the patient that is as comprehensive as possible (extending from diagnostics to treatment and rehabilitation). In the case of movements to healthcare within the city of Bydgoszcz, no substantial differences between males and females are to be noted.

\section{References}

Aldred R., Woodcock J., 2008. Transport: Challenging disabling environments. Local Environment, vol. 13, no. 6, pp. 485-496.

Anderson C.A., 2001. Claiming disability in the field of geography: Access, recognition and integration. Social and Cultural Geography, vol. 2, no. 1, pp. 87-93.

Anderson P., KitChin R., 2000. Disability, space and sexuality: Access to family planning services. Social Science and Medicine, vol. 51, no. 8, pp. 1163-1173.

Barnes C., Mercer G., 2008. Niepełnosprawność. Warszawa: Wydawnictwo Sic!, 219 pp.

Barrett E., Heycock M., Hick D., Judge E., 2003. Issues in access for disabled people. The case of the Leeds Transport Strategy. Policy Studies, vol. 24, no. 4, pp. 227-242.
In contrast, able-bodied counterparts from the same households as disabled people are inclined to choose local clinics situated near their home areas (every second journey is just to a neighbouring micro-area). This suggests that the help of general practitioners rather than specialists is being sought by non-disabled members of households.

In the case of disabled people travelling to healthcare, the first principal component describes well-educated people with multi-organ dysfunctions and a slight or moderate degree of impairment, the second component - mainly disabled people travelling to healthcare by motorcycle, and the third - people with substantial impairment, poorly-educated, with sight problems and travelling by bus.

Non-disabled counterparts are described by a first component that characterises poorlyeducated (primary-only) people moving on foot or by taxi, the second component indicating passengers travelling to a doctor by car, and the third presenting poorly-educated (vocational trainingonly) people commuting by tram. The transport factor seems to be more important in the case of able-bodied respondents, rather than such sociodemographic features as age, gender, or even educational level.

\section{Editor's note:}

Unless otherwise stated, the sources of tables and figures are the authors, on the basis of their own research.

Brown L., Boardman F.K., 2011. Accessing the field: Disability and the research process. Social Science and Medicine, vol. 71, no. 1, pp. 23-30.

Butler R., Bowlby S., 1997. Bodies and spaces: An exploration of disabled people's experiences of public space. Environment and Planning D: Society and Space, vol. 15, no. 4, pp. 411-433.

Butler R., Parr H. (eds.), 1999. Mind and body spaces: geographies of illness, impairment and disability. London-New York: Routledge, 307 pp.

CASAS I., 2007. Social exclusion and the disabled: An accessibility approach. Professional Geographer, vol. 59, no. 4, pp. 463-477.

Casas I., Horner M.W., Weber J., 2009. A comparison of three methods for identifying transport-based exclusion: A case study of children's access to urban 
opportunities in Erie and Niagara counties, New York. International Journal of Sustainable Transportation, vol. 3, no. 4, pp. 227-245.

ChouInARD V., 1997. Making space for disabling differences: Challenging ableist geographies. Environment and Planning D: Society and Space, vol. 15, no. 4, pp. 379-387.

Clarke P.J., Ailshire J.A., Nieuwenhuijsen E.R., de KlelJN-DE VRANKRIJKer M.W., 2011. Participation among adults with disability: The role of the urban environment. Social Science and Medicine, vol. 72, no. 10, pp. 1674-1684.

Crooks V.A., Chouinard V., 2006. An embodied geography of disablement: Chronically ill women's struggles for enabling places in spaces of health care and daily life. Health \& Place, vol. 12, no. 3, pp. 345-352.

Crooks V.A., Dorn M.L., WILTON R.D., 2008. Emerging scholarship in the geographies of disability. Health \& Place, vol. 14, no. 4, pp. 883-888.

FILIPEK M., 2006. Osoby niepełnosprawne w Jaworznie. [in:] J. Słodczyk, E. Szafranek (eds.), Kierunki przekształceń struktury gospodarczej i społeczno-demograficznej miast, Opole: Uniwersytet Opolski, pp. 549-561.

GAŁKOWSKI A., 1999. Architektoniczne i urbanistyczne uwarunkowania udostępnienia infrastruktury transportowej dla osób niepełnosprawnych. [in:] II Konferencja naukowa. Rozwój środków lokomocji dla osób niepełnosprawnych. Kraków: Wydawnictwo Instytutu Gospodarki Surowcami Mineralnymi i Energia PAN, pp. 37-44.

GANT R., 1992. Transport for the disabled. Geography, vol. 77, no. 1, pp. 88-91.

GANT R., 1997a. Pedestrianisation and disabled people: A study of personal mobility in Kingston town centre. Disability \& Society, vol. 12, no. 5, pp. 723-740.

GANT R., 1997b. Elderly people, personal mobility and local environment. Geography, vol. 82, no. 3, pp. 207-217.

GANT R., 2002. Shopmobility at the millennium: 'Enabling' access in town centres. Journal of Transport Geography, vol. 10, no. 2, pp. 123-133.

GANT R., SMith J., 1998. Shopmobility, personal mobility and disabled people. Geography, vol. 83, no. 3, pp. 280-283.

GLEESON B.J., 1996. A geography for disabled people? Transactions of the Institute of British Geographers, N.S., vol. 21, no. 2, pp. 387-396.

GleESON B., 1997. Community care and disability: The limits to justice. Progress in Human Geography, vol. 21, no. 2, pp. 199-224.

GleESON B., 1999. Geographies of disability. LondonNew York: Routledge, 253 pp.
Golledge R.G., 1993. Geography and the disabled: a survey with special reference to vision impaired and blind populations. Transactions of the Institute of British Geographers, N.S., vol. 18, no. 1, pp. 63-85.

Golledge R.G., 1997. On reassembling one's life: overcoming disability in the academic environment. Environment and Planning D: Society and Space, vol. 15, no. 4, pp. 391-409.

GorczYCKA E., 1999. Dostosowanie środowiska do potrzeb lokomocyjnych osób niepełnosprawnych na przykładzie wybranych elementów infrastruktury miasta. [in:] II Konferencja naukowa. Rozwój środków lokomocji dla osób niepełnosprawnych. Kraków: Wydawnictwo Instytutu Gospodarki Surowcami Mineralnymi i Energia PAN, pp. 45-51.

Grabowska-PaŁeCKa H., 2004. Niepetnosprawni w obszarach i obiektach zabytkowych. Problemy dostępności. Seria Monografia. Architektura, vol. 304, Kraków: Wydawnictwo Politechniki Krakowskiej, 229 pp.

Grady J., OhuIn J.B., 2009. Equal access to hospitality services for guests with mobility impairments under the Americans with Disabilities Act: Implications for the hospitality industry. International Journal of Hospitality Management, vol. 28, no. 1, pp. 161-169.

HaLL E., 2004. Social geographies of learning disability: Narratives of exclusion and inclusion. Area, vol. 36, no. 3, pp. 298-306.

Hall E., Kearns R., 2001. Making space for the 'intellectual' in geographies of disability. Health \& Place, vol. 7, no. 3, pp. 237-246

Hall T., Healey M., Harrison M., 2002. Fieldwork and disabled students: Discourses of exclusion and inclusion. Transactions of the Institute of British Geographers, N.S., vol. 27, no. 2, pp. 213-231.

Hine J., Kamruzzaman M., 2012. Journeys to health services in Great Britain: An analysis of changing travel patterns 1985-2006. Health \& Place, vol. 18, no. 2, pp. 274-285.

Hine J., Mitchell F., 2001. Better for everyone? Travel experiences and transport exclusion. Urban Studies, vol. 38, no. 2, pp. 319-332.

IMRIE R. 1996b. Disability and the city: International perspectives. London: Sage Publications, 208 pp.

IMRIE R., 1996a. Ableist geographies, disablist spaces: Towards a reconstruction of Golledge's 'Geography and the Disabled'. Transactions of the Institute of British Geographers, N.S., vol. 21, no. 2, pp. 397-403.

IMRIE R., 2000. Disability and discourses of mobility and movement. Environment and Planning A, vol. 32, no. 9, 1641-1656. 
ImRIE R., EDWARDS C., 2007. The geographies of disability: Reflections on the development of a sub-discipline. Geography Compass, vol. 1, no. 3, pp. 623-640.

Iwarsson S., Jensen G., Ståhl A., 2000. Travel Chain Enabler: Development of a pilot instrument for assessment of urban public bus transport accessibility. Technology and Disability, vol. 12, no. 1, pp. 3-12.

Józefowicz I., 2006. Bydgoszcz - przyjazne miasto? Dostępność przestrzenna wybranych funkcji dla potrzeb osób niepetnosprawnych. [in:] H. Ochonczenko, M.A. Paszkowicz (eds.), Potrzeby osób niepełnosprawnych w warunkach globalnych przemian społeczno-gospodarczych. Tom 2, Kraków: Oficyna Wydawnicza Impuls, pp. 301-312.

Józefowicz I., 2007. Sport dla wszystkich... Możliwości rekreacji ruchowej niepełnosprawnych mieszkańców Bydgoszczy. Prace Komisji Geografii Komunikacji PTG, vol. 13, Warszawa-Rzeszów: Komisja Geografii Komunikacji Polskiego Towarzystwa Geograficznego w Warszawie, Wydział Ekonomii Uniwersytetu Rzeszowskiego, pp. 281-291.

Kearns R., Moon G., 2002. From medical to health geography: Novelty, place and theory after a decade of change. Progress in Human Geography, vol. 26, no. 5, pp. 605-625.

KITCHIN R., 1998. 'Out of place', 'knowing one's place': Space, power and the exclusion of disabled people. Disability \& Society, vol. 13, no. 3, pp. 343-356.

KITCHIN R., 2000. The researched opinions on research: Disabled people and disability research. Disability \& Society, vol. 15, no. 1, pp. 25-47.

KITCHIN R., 2001. Investigating disability and inclusive landscapes. Teaching Geography, vol. 26, no. 2, pp. 81-85.

KITCHIN R., WILTON R., 2000. Disability, geography and ethics. Ethics, Place and Environment, vol. 3, no. 1, pp. 61-65.

Matthews H., Beale L., Picton P., Briggs D., 2003. Modelling access with GIS in urban systems (MAGUS): Capturing the experiences of wheelchair users. Area, vol. 35 , no. 1, pp. 34-45.

McManus B.M., Carle A.C., Acevedo-Garcia D., Ganz M., Hauser-Cram P., McCormick M.C., 2011. Social determinants of state variation in special education participation among preschoolers with developmental delays and disabilities. Health \& Place, vol. 17, no. 2, pp. 681-690.

MiLlaRd F., 1995, Changes in the health care system in post-Communist Poland. Health \& Place, vol. 1, no. 3, pp. 179-188.

Morris H.T., Snelson A., 1994. An improved road environment for older and disabled drivers. [in:] J. Smith (ed.), Transport and welfare. Salford: Transport Geog- raphy Study Group at the Department of Geography. University of Salford, pp.77-84.

Ostrowska A., Sikorska J., Gaciarz B., 2001. Osoby niepełnosprawne $w$ Polsce w latach dziewięćdziesiqtych. Warszawa: Instytut Spraw Publicznych, 191 pp.

OXLEY P.R., RICHARDS M.J., 1995. Disability and transport: A review of the personal costs of disability in relation to transport. Transport Policy, vol. 2, no. 1, pp. 57-65.

Park D.C., Radford J.P., Vickers M.H., 1998. Disability studies in human geography. Progress in Human Geography, vol. 22, no. 2, pp. 208-233.

PARR H., 1997. Mental health, public space, and the city: Questions of individual and collective access. Environment and Planning D: Society and Space, vol. 15, no. 4, pp. 435-454.

Philo Ch., Metzel D.S., 2005. Introduction to theme section on geographies of intellectual disability: 'Outside the participatory mainstream'. Health \& Place, vol. 11, no. 2, pp. 77-85.

Porter A., 2000. Playing the 'disabled role' in local travel. Area, vol. 32, no. 1, pp. 41-48.

Powell M., 1995. On the outside looking in: Medical geography, medical geographers and access to health care. Health \& Place, vol. 1, no. 1, pp. 41-50.

Preston J., RaJé F., 2007. Accessibility, mobility and transport-related social exclusion. Journal of Transport Geography, vol. 15, no. 3, pp. 151-160.

Schmöcker J.-D., Quddus M.A., Noland R.B., Bell M.G.H., 2008. Mode choice of older and disabled people: A case study of shopping trips in London. Journal of Transport Geography, vol. 16, no. 4, pp. 257-267.

SMith P., 2005. Off the map: A critical geography of intellectual disabilities. Health \& Place, vol. 11, no. 2, pp. 87-92.

TAYLOR Z., JÓzefOWICZ I., 2012a. Intra-urban daily mobility of disabled people for recreational and leisure purposes. Journal of Transport Geography, vol. 24, pp. 155-172.

TAYLOR Z., JÓzefowiCZ I., 2012b. Geograficzne badania niepełnosprawności ze szczególnym uwzględnieniem codziennej ruchliwości osób niepełnosprawnych w przestrzeni miasta-częśćl. Przegląd Geograficzny, vol. 84, no. 2, pp. 261-278.

TAYlor Z., Józefowicz I., 2012c. Geograficzne badania niepełnosprawności ze szczególnym uwzględnieniem codziennej ruchliwości osób niepełnosprawnych w przestrzeni miasta - część II. Przegląd Geograficzny, vol. 84, no. 4, pp. 529-558.

Thomas C., 1999. Female forms: Experiencing and understanding disability. Buckingham-Philadelphia: Open University Press, 175 pp. 
Trani J.-F., Browne J., Kett M., Bah O., Morlai T., NalLEY N., GRoce N., 2011. Access to health care, reproductive health and disability: A large scale survey in Sierra Leone. Social Science and Medicine, vol. 73, no. 10, pp. 1477-1489.

Urbanowicz U., Burda-ŚWierz K., 2006. Dostęp osób niepełnosprawnych do opieki zdrowotnej i rehabilitacyjnej w dobie globalnych przemian społeczno-gospodarczych. [in:] H. Ochonczenko, A. Nowicka (eds.), Potrzeby osób niepełnosprawnych w warunkach globalnych przemian społeczno-gospodarczych, Kraków: Oficyna Wydawnicza Impuls, pp. 221-232.
VAlentine G., 2003. Geography and ethics: In pursuit of social justice - ethics and emotions in geographies of health and disability research. Progress in Human Geography, vol. 27, no. 3, pp. 375-380.

Yau M.K., MCKercher B., PACKer T.L., 2004. Traveling with a disability. More than an access issue. Annals of Tourism Research, vol. 31, no. 4, pp. 946-960.

Yee S., BresLin M.L., 2010. Achieving accessible health care for people with disabilities: Why the ADA is only part of the solution. Disability and Health Journal, vol. 3, no. 4, pp. 253-261. 